\title{
Lingering Concerns about Child Custody and Support
}

\author{
Maureen Baker
}

\section{Introduction}

Since the 1970s, separation and divorce rates have increased in most Western countries, reflecting broad societal changes such as growing secularisation and individualism, changing labour markets and migration patterns, new ideas about entitlements and obligations, and widespread legal reforms. Despite these changes, most people agree that children in the 'post-divorce family' deserve adequate living standards and the continued love and support of both parents (BeckGernsheim, 2002). In addition, supporting one's children is required by national laws and international agreements such as the United Nations' Convention on the Rights of the Child (Baker, 2006).

Over the past three decades, New Zealand as well as Australia, Canada, the United Kingdom and the United States ('liberal welfare states') have reformed their social policies relating to custody and support to reflect evolving ideas about children's rights, gender equity, and the state's role in family life. This article discusses some of the policy implications of relationship breakdown at a time when fewer couples legally marry, separation rates are high, more mothers are employed, international travel has increased and the enforcement of certain family obligations has been tightened.

New Zealand policies are discussed together with those of Canada and Australia because these countries share a common legal and policy heritage as British colonies, ${ }^{2}$ they have been categorised as liberal welfare states and have traded policy solutions in the past. In addition, their net migration rates are particularly high and an increasing number of residents have dual citizenship (OECD, 2007, p.47). As more people migrate for education, work and family reasons, intermarriage and childbearing become prevalent between partners from different jurisdictions. If relationships dissolve after children are born, resident or custodial parents ${ }^{3}$ may cross international borders to return home but they sometimes do so unlawfully, without the consent of the other parent. Parents also cross borders to avoid support obligations, to flee from abusive partners or to gain child custody. Increasingly, governments are signing international agreements to help deal with parents who cross borders without fulfilling their spousal or parental obligations. However, the vast majority of couples resolve custody and support issues without assistance from the courts.

Despite the development of social programmes for caring, such as the Domestic Purposes Benefit, children living in sole-parent households continue to experience higher poverty rates ${ }^{4}$ than those in twoparent households (OECD, 2005, p.57). Policy concern about sole-parent households has also reflected a number of other children's issues that sometimes correlate with low income, including adjustment problems, reduced paternal contact, and lack of cooperative and authoritative parenting (Pryor and Rodgers, 2001). The public cost of caring allowances has also increased with more marriage breakdown, cohabitation and births outside marriage.

This article focuses more on mother-led households than father-led households because most children live with their mothers after separation, fewer mothers than fathers are employed, more mothers have relied on costly caring allowances, and mothers remain sole parents longer than fathers (Baker \& Tippin, 1999).

1 'Liberal welfare regimes' refer to systems of social provision that rely mainly on individual earnings while providing relatively ungenerous public support to needy households.

2 Except the French Canadian province of Quebec.

3 Separated parents who normally live with and care for their children most of the time.

4 Defined as less than $50 \%$ of median household income adjusted for family size. 
The percentage of sole mothers receiving caring benefits has varied over the years but has always been higher in Australia and New Zealand than in Canada. For example, $94 \%$ of sole mothers in Australia and 89\% in New Zealand received caring allowances in the mid1990s, compared to about $44 \%$ in Canada (Baker \& Tippin, 1999, p.34). Now, more sole mothers rely on their earnings, although those in Australia are permitted to receive the benefit for longer than in New Zealand and much longer than in Canada (Baker, 2006). ${ }^{5}$

Reducing the public cost of income support has been a major factor in recent social policy reform (Baker \& Tippin, 1999; Boyd, 2003). Policy makers have struggled to alleviate poverty in sole-parent households and reduce the negative consequences of separation for children. However, they have tended to focus on collecting money from non-resident parents and curbing the cost of income support. At the same time, policy reforms have had to deal with the complex lives of post-separation parents (Callister \& Birks, 2006), with mothers and fathers sometimes making conflicting demands for state intervention.

This article discusses several policy concerns relating to the post-divorce family in New Zealand, Canada and Australia, in order to highlight the complexity and show that these countries, which have shared policy options in the past, can continue to learn from cross-national comparisons.

\section{Family reforms in the 1980s}

With rising separation/divorce rates and more soleparent households living on income support, policy makers were pressed to make controversial reforms throughout the 1980s. In all three countries, divorce is now viewed as a 'clean break' which terminates rights and responsibilities to marriage partners but not obligations to children. The laws now permit one partner to seek a divorce without the other's consent, meaning that wives can no longer delay court proceedings to negotiate a better financial settlement, as some did in the past, and spousal support is seldom paid. Furthermore, all three countries assume that separating parents can decide child custody and access for themselves and the courts intervene only when requested (Baker, 2006). By the 1970s, these countries had rejected the implication that children could be parental 'property' and began basing decisions about guardianship and residence on the 'best interests of the child'. However, even judges disagree about what is best and children often prefer to live with both parents even when it is no longer feasible. Nevertheless, in all three countries, separating parents appearing before the courts are required to make parenting plans with the assistance of counselling and mediation services (ibid).

Although joint custody/guardianship ${ }^{6}$ has become more prevalent since the 1980s, it refers to legal responsibility rather than shared day-to-day care. Consequently, about three-quarters of children involved in divorce cases continue to live mostly with their mothers, but rates are higher for children of separated, never-married parents. Fathers typically become the non-resident parent but retain access or opportunities to visit or have the child stay overnight for a portion of the week, month or year (Baker, 2006). Both parents usually agree with this arrangement, the courts legalise it and parents rarely contest the decisions in court. Many fathers feel they cannot handle daily childcare while working full time, or believe that their children are better off with their mother. A small percentage of fathers say they want custody but think the courts will not give it to them, and a few protest over the courts' alleged discrimination against fathers. By the 1990s, all three countries expected fathers to support their children regardless of their marital status or living arrangements (Funder, 1996; Shirley et al., 1997; Baker, 2006). New technology better enables the establishment of paternity and some jurisdictions spend considerable resources trying to identify fathers and enforce support.

After divorce, most non-resident fathers visit and support their children emotionally and financially, but only one third are highly involved in their care and upbringing. Another third are disengaged but maintain some contact, while the final third have little or no contact (Amato, 2004; Smyth, 2004). 'Fading fathers' (Dulac, 1995) may enter the divorce with little interest in their children or become alienated afterwards

5 In Australia, parents (mainly mothers) are permittd to receive the benefit until their youngest child is 16 years old, although there is pressure to seek employment before then. In New Zealand, similar pressure occurs when the age is 12 years (although there is no longer an official age). In contrast, the Canadian province of Alberta expects a 'welfare mother' to seek employment when her youngest child is 6 months old and all other provinces expect maternal employment when the youngest child is from 2 to 6 years old.

6 The terminology differs slightly in each country. 
due to perceived difficulties visiting or maintaining a meaningful relationship. Some fathers rekindle interest after divorce and become 'weekend parents', while others attempt to alter existing custody or access arrangements (Beck-Gernsheim, 2002).

Fathers are legally required to support their children but enforcement procedures used to be lax in the three countries (Baker, 2001). If the father failed to make court-awarded payments before the 1990s, the children's mother was expected to take him to court, which meant she had to prove he was the father, know where he lived, take him to court in the jurisdiction where he lived and pay the expenses. These procedures were too complicated and expensive for most mothers. As divorce rates soared and default rates remained high, governments were pressured to develop caring allowances in the 1970s and to reform child support in the 1980s. Before reform, two-thirds to three-quarters of fathers failed to pay the full amount of court-awarded support within a few years of divorce and many solemother households relied on income support (Funder, 1996; Baker \& Tippin, 1999).

In the late 1980s, Wisconsin and Australia developed new procedures that took child support assessment out of the courts, based it on a percentage of the nonresident parent's income (with a disregard), and collected support through the income tax system. New Zealand adopted a similar model to Australia (discussed below), but Canada could not agree to develop a unified system with its divided jurisdiction. ${ }^{7}$ All the Canadian provinces tightened their enforcement procedures but awards are still set by judges in court, based on national guidelines. Some provinces focus enforcement on 'welfare families', while others use the 'first default principle', meaning that the government scheme is activated only when unpaid child support is reported. Since 1987, the federal government has assisted the provinces with enforcement tools, including sharing information to locate and intercept defaulters and suspending or denying passports (Canadian Department of Justice, 2003). However, many custodial parents are forced to take the initiative to set enforcement procedures in motion, and variations in provincial rules make national enforcement difficult when parents move to another province.

New Zealand followed the more efficient Australian model and created a child support agency, removed assessment from the courts, empowered the taxation department to calculate money owed, and paid support indirectly through the agency to avoid parental contact and conflict. The new schemes in the three countries have increased the percentage of children receiving support and marginally increased the amounts paid and collected, thus saving some public money (Baker, 2006). However, the effectiveness of the new procedures is disputed and the amount collected varies by jurisdiction, as governments use different ways of measuring collection (Baker \& Tippin, 1999). ${ }^{8}$ In all three countries, the state has been unable to collect the full amount due from many non-resident parents, especially men who are less affluent, self-employed, unemployed, difficult to trace, never married, out of contact with their children, or who separated long ago (Smyth, 2004).

Since the 1950s governments have been encouraged to sign multilateral and bilateral agreements regarding a number of policy issues, including the right to live and work in other countries (such as between Australia and New Zealand) and the enforcement of child custody, access and support (Baker, 2006). Recently, the number of agreements has increased, as well as the controversies surrounding them, as I discuss in the next section.

\section{International agreements on child support and custody}

International conventions to ensure the enforcement of support obligations when parents cross international borders date back to 1956, with the United Nations Convention on the Recovery Abroad of Maintenance. More recent agreements include the 1968 Brussels Convention and the 1973 Hague Convention on the Recognition and Enforcement of Decisions Relating to Maintenance Obligations (UK Child Support Agency, 2003). Governments also sign bilateral agreements with individual countries to enforce child support and custody arrangements and to apprehend and return offenders. For example, agreements have been signed between Canada and the United States, Australia and

7 The provinces assess and enforce child support, and the federal government has no constitutional right to establish a national system

8 In Australia, the Child Support Agency claimed a $73 \%$ collection rate, but this figure was disputed by researchers arguing that partial or late payments should be excluded or noted separately, and that parents who cannot pay should still be included in the data (Alexander, 1995). These rates are also contested in other jurisdictions. 
New Zealand, and Australia and the United States (Australian Parliament, 2003).

Before entering these agreements, states must develop clear procedures to establish paternity and support orders, enforce support, and collect and distribute payments. They must also be willing to provide administrative and legal assistance to the country seeking co-operation without additional cost to that country. And finally, a central authority is needed to facilitate the implementation of support enforcement, especially in countries such as Canada and the United States where enforcement is administered by the provincial or state governments (US Department of State, 2003). An application to retrieve child support from someone living in another jurisdiction has to be processed according to the laws of that jurisdiction. In other words, effective reciprocal agreements require considerable co-operation and consistency in laws, procedures and practices. In addition, compliance involves additional costs for signatory countries in policing, administrative work, legal fees and court time, and transport costs when they send offenders back home.

The three countries have also signed multilateral agreements relating to child custody and access disputes. The Hague Convention on the Civil Aspects of International Child Abduction is the primary international treaty dealing with custody, and was opened for signatures in 1980 (Crouch, 2003). The convention's provisions are available for citizens if one parent from a signatory country moves to another signatory country with a child under 16 against the objections of the other parent. While the Hague Convention is a standard treaty, different jurisdictions interpret and implement its clauses in various ways (Jaffe et al., 2003, p.111). A discussion of this convention illustrates some of the concerns about interpretation, implementation and compliance costs.

The primary goal of the Hague Convention is to reinstate the status quo, implying that the child's best interests are served by being returned quickly to the place of habitual residence. An investigation into either parent's circumstances is discouraged and oral evidence by either party is generally disallowed. The convention assumes that children's interests are best protected in their home country because their courts will be able to carry out a thorough hearing and determine and enforce custody and access issues (Kaye, 1999, p.195). However, the operation of this convention depends upon the goodwill of signatory countries and contains no legally binding force to ensure compliance.

The Hague Convention states that exceptions to a child's return are allowed if there is a 'grave risk' that the return would expose the child to physical or psychological harm or otherwise place the child in an intolerable situation' (article 13b, Hague Convention, 1980). This is sometimes interpreted to include domestic violence, but several researchers argue that the convention offers few protections from abusive partners or inhumane treatment by officials of the return state, and provides no guarantee of fair and impartial hearings in custody matters (Kaye, 1999; Jaffe et al., 2003, p.62). In the three countries, most decisions under the Hague agreement have ordered the child to be returned to the home country, denying that there was any 'grave risk' in doing so (ibid). New Zealand, for example, has dealt with at least two cases under the Hague agreement and in both cases the court concluded that there was no grave risk to the children and ordered them to be returned to their home countries.

Child custody and access decisions have increasingly reflected awareness of the detrimental impact that domestic violence has on children. However, a common interpretation of the Hague Convention is that the most expeditious way to deal with cases is to send children back home. This is viewed as returning the child to the care of the country rather than the individual abuser, and the country is expected to adequately hear and enforce custody issues and to protect the child and parent from further domestic violence. However, this assumption may not always be justifiable.

\section{Lingering policy concerns}

A major concern in the post-divorce family is the negative impact of poverty on children, and mother-led households are most likely to experience low income. In response, all three countries have urged these mothers to seek employment and have made recent improvements to child care and child benefits (Baker, 2007b). However, poverty rates remain high as marital separation increases and parents subsequently divide their incomes and assets, labour markets become more competitive, and fewer jobs are full-time and protected by legislation or unions. Of the three countries, poverty rates have been the highest in Canada, where nearly half of sole-parent 
households are poor, but these rates are considerably lower in the Nordic countries, suggesting that policy reforms can be effective (OECD, 2005, p.57). New Zealand has since introduced 'Working for Families', which should reduce poverty, and Australia and Canada have improved child benefits and childcare support, but living costs have also increased (Baker, 2007b).

If sole parents are outside the workforce their poverty rates rise to $89.7 \%$ in Canada, $87.6 \%$ in New Zealand and $58.7 \%$ in Australia, reflecting tighter eligibility rules and lower levels of state income support in Canada and New Zealand (OECD, 2005, p.57). However, poverty rates are influenced by many other factors, including income tax policies, ${ }^{9}$ low wages, and part-time or temporary jobs that are often accepted by mothers with pre-school children. When sole parents enter paid work (part-time or full-time), their household poverty rates decline, but over $21 \%$ remain poor in New Zealand (compared to $28 \%$ in Canada and $12 \%$ in Australia) (ibid). The high Canadian rate reflects low wages and the higher gender wage gap in that country (OECD, 2007, p.73) but parents in all three countries must also contend with soaring housing and childcare expenses.

Childcare costs have been especially high in New Zealand, where sole parents on average earnings with two children at home have been spending $42 \%$ of their earnings on childcare, compared to $27 \%$ in Canada and $17 \%$ in Australia (OECD, 2007, p.59). However, all three countries (or jurisdictions within them) have recently reduced specific childcare costs. For example, Quebec heavily subsidised childcare to all parents who need it, regardless of employment status, for a maximum price of $\$ 7.00$ per day, and New Zealand initiated free childcare for 20 hours a week for 3-4 year olds in educational care in 2007 (Baker, 2007b). Canada also offers a substantial income tax deduction for childcare expenses of employed parents. Research has found that reducing childcare costs increases maternal employment (Roy, 2006).

The second lingering concern is the way that child support is calculated. Canadian researchers suggest that national child support guidelines are inequitable because they consider the non-resident parent's income but not his net assets or expenses. They also fail to adequately acknowledge the resident parent's income and assets, or the children's financial needs (Wu \& Schimmele, 2005). The same could be said for Australia and New
Zealand. Furthermore, self-employed parents do not always declare their full income to governments. Increasingly, separated parents find new partners and produce or acquire additional children to support. In some jurisdictions, support priority is given to children living in the household, while others give priority to children from previous relationships (Baker \& Tippin, 1999). Debates also continue about how to consider hidden expenses, gifts and the costs of shared parenting, especially when the child lives in the household for less than half the time. Finally, the minimum child support payment required by government remains low in many places, such as $\$ 10$ per week in New Zealand, which clearly does not cover many childrearing costs.

The third issue concerns the numerous cases that remain 'in default', meaning that the parent failed to pay the total amount, the payment arrived late or the payment was not made. One Canadian study in New Brunswick (Lapointe \& Richardson, 1994) found that only $58 \%$ of cases involved full compliance after reform, with 10\% of parents explicitly refusing to pay. The rest involved temporary non-payment or disputes about the amount, but failure to pay is clearly associated with perceived access difficulties. Fathers often blame the children's mother for denying or complicating access, while mothers complain about paternal irregularities in access visits or inadequate care (Amato, 2004; Smyth, 2004).

Fathers also change their minds after legal custody and access arrangements are confirmed in court. The Australian Institute of Family Studies found that 41\% of non-resident fathers wanted to alter the children's living arrangements five years after separation: twothirds wanted the children to live with them and the rest wanted equal care (Smyth, Sheehan \& Fehlberg, 2001). Parents also disagree about the amount of contact fathers actually have, with non-resident fathers reporting more child contact than resident mothers confirm. In addition, some fathers argue that support payments should be reduced to compensate for shared care. Although many people believe that child support legislation ought to foster and facilitate parent-child contact, legislators have argued that linking father-child contact with child support is not in the best interests of the child (Smyth, 2004).

Both Canada and Australia have substantial personal tax deductions that are beneficial to low-income households. 
More women than men initiate separation ${ }^{10}$ but sole parenthood is usually a transitional stage for both (Baker $\&$ Tippin, 1999). However, about three-quarters of men and two-thirds of women re-partner within five years, and men re-partner faster. In addition, remarriage rates are declining with more cohabitation, but cohabitation leads to higher separation rates than legal marriage (Baker, 2006). Nevertheless, re-partnering rates reflect both choices and constraints. For example, beneficiary mothers lose their income support if they cohabit with or marry an employed man, and men do not always consider 'welfare mothers' as desirable partners. Negative marital experiences further discourage former partners from remarriage. In addition, men tend to marry women younger than themselves, especially in second or subsequent marriages, and fewer older men are available in the population (Baker, 2007a).

A fourth concern relates to cases of child 'abduction', which receive considerable media attention. 'Child abductors' are often portrayed as non-resident fathers trying to obtain custody, but most Hague Convention cases involve mothers who are primary caregivers taking their children back to the mother's home country, with an increasing number reporting that they are fleeing from abusive partners (Coester-Waltjen, 2000). Some researchers have argued that the Hague Convention allows little room for mothers' fear of violence if they are expected to return to the country where their children normally live (Kaye, 1999, pp.197-8). A common judicial response to allegations of domestic violence is to issue the remiss parent with 'undertakings', such as attending a stopping violence programme and/or abiding by protection orders. Yet these cannot be legally enforced in the countries concerned (Coster-Waltjen, 2000, p.68).

As more parents travel internationally, live with partners from other countries and receive dual citizenship, the state needs to ensure that non-resident parents are guaranteed access to their child unless there is a valid reason to restrict access. However, access cannot compromise the safety and well-being of the resident parent or child, and existing laws about crossing borders with unmet family obligations need to be enforced.

10 But they often blame their male partner for prior adultery, abuse lack of consideration and/or unequal division of labour at home.

\section{Conclusion}

New Zealand, Australia and Canada have experienced similar increases in marriage breakdown, migration and family poverty. In all three countries, governments have developed gender-neutral laws and programmes relating to divorce, child support and custody. In deciding where the post-separation child should live, they all emphasise the best interests of the child and encourage parental co-operation over access and care arrangements. Although most separating parents manage these issues without much formal assistance, all three governments have attempted to ensure that family courts include mediation and less adversarial practices (Baker, 2006). Yet debates continue about how to deal with complicated parenting arrangements and lingering disputes between former partners.

The post-separation processes set out in laws and policies in the three countries have been unable to compensate for the gendered nature of paid and unpaid work, which creates economic inequalities between partners that continue after separation. Many mothers work part time in order to retain caring responsibilities, especially in Australia and New Zealand, but in doing so these mothers reduce their household earnings. When marriages end, mothers with young children often need a transitional period of income support but it seldom pays above the minimum wage. Most children continue to live with their separated mother even though the laws are gender-neutral. Mother-led households tend to experience an income drop even when these mothers work for pay, as families increasingly need two incomes and male earnings still tend to be higher than female earnings. Many fathers still fail to pay the required amount of child support on time, and some lose contact with children from previous relationships. Few nonresident parents can earn enough to support children in more than one household, especially in today's less regulated labour market.

More international travel has encouraged governments to sign international agreements to enforce parental obligations, but these agreements require co-operation between jurisdictions, a convergence in enforcement procedures and heavy reliance on national enforcement. International pressure to restructure family policies increases when markets become international and investors and employers promote neo-liberal labour practices. At the same time, interest groups press for 
new entitlements, often making contradictory demands that complicate the reform process.

Caring for children constrains employment opportunities unless incomes are high enough to purchase care, but childcare continues to be expensive in many jurisdictions and is not always available when needed for employment. Most politicians publicly say that children should not have to live in poverty, but few states have successfully bridged the poverty gap between two-parent and one-parent households. These concerns linger in the liberal states but have been less problematic in the social democratic states, where children's well-being is viewed more as a public responsibility. In contrast, the liberal states have devoted fewer resources to family income support, universal children's services and family-related employment benefits (Jenson \& Sineau, 2001; Hantrais, 2004; Baker, 2006).

This discussion reveals some of the complexity of current concerns about post-divorce families. New Zealand has developed relatively effective procedures to deal with child custody and support, especially compared to some Canadian provinces, but it is worth reiterating some findings from the research:

- Child support enforcement mechanisms must be automatic rather than dependent on parental complaints about non-payment.

- The income, assets and major gifts from both parents need to be considered in assessing child support.

- Minimum levels of parental support and caring allowances need to be high enough to keep children out of poverty.

- Existing laws that prohibit parents owing child support from leaving the country need to be enforced.

- Witnessing parental violence and a genuine fear of partner violence require more careful consideration in custody cases.

- Childcare services need to be affordable and accessible to enable parents to become self-supporting.

- Policy makers need to acknowledge that mothers and fathers seldom have comparable earnings, they typically perform different amounts of caring work, and often have different perspectives on the postdivorce family.

\section{References}

Alexander, L. (1995) 'Australia's child support scheme', Family Matters, 2, spring/summer, pp.6-11

Amato, P. (2004) 'Parenting through family transitions', Social Policy Journal of New Zealand, 23 (December), pp.31-44

Australian Parliament (2003), www.aph.gov.au

Baker, M. (2001) Families, Labour and Love: family diversity in a changing world, Sydney: Allen and Unwin; Vancouver: UBC Press

— (2006) Restructuring Family Policies: convergences and divergences, Toronto: University of Toronto Press

(2007a) Choices and Constraints in Family Life, Toronto: Oxford University Press

_ (2007b) 'Managing the risk of childhood poverty: changing interventions by the state', Women's Health and Urban Life, 6 (2), pp.8-21

Baker, M. \& D. Tippin (1999) Poverty, Social Assistance and the Employability of Mothers: restructuring welfare states, Toronto: University of Toronto Press

Beck-Gernsheim, E. (2002) Reinventing the Family: in search of new lifestyles, Cambridge: Polity

Boyd, S.B. (2003) Child Custody, Law, and Women's Work, Toronto: Oxford University Press

Callister, P. \& S. Birks (2006) Two Parents, Two Households: New Zealand data collections, language and complex parenting, Wellington: Families Commission

Canadian Department of Justice (2003) 'Child Support', http://canada.justice.gc.ca/en/ps/sup/index.html

Coester-Waltjen, D. (2000) 'The future of the Hague Child Abduction Convention: the rise of domestic and international tensions - the European perspective', International Law and Politics, 33, pp.59-82

Crouch, J. (2003) 'The Hague Convention on the Civil Aspects of International Child Abduction', http:// patriot.net/ $\sim$ crouch/flnc/hague.html

Dulac, G. (1995) 'Rupture d'union et deconstruction du lien père-enfant', Prisme, 5 (3), summer, pp.300-12

Funder, K. (1996) Remaking Families: adaptation of parents and children to divorce, Melbourne: Australian Institute of Family Studies 
Hague Conference on Private International Law (1980) 'Convention on the Civil Aspects of International Child Abduction', 25 October 1980, www.hcch.net/e/ conventions/text28e.html

Hantrais, L. (2004) Family Policy Matters: responding to family change in Europe, Bristol: The Policy Press

Jaffe, P., N. Lemon \& S. Poisson (2003) Child Custody and Domestic Violence: a call for safety and accountability, London: Thousand Oaks; New Delhi: Sage

Jenson, J. \& M. Sineau (2001) Who Cares? Women's work, childcare, and welfare state design, Toronto: University of Toronto Press

Kaye, M. (1999) 'The Hague Convention and the flight from domestic violence: how women are being returned by coach and four', International Journal of Law, Policy and the Family, 13 (2), pp.191-212

Lapointe, R.E. \& C.J. Richardson (1994) Evaluation of the New Brunswick Family Support Orders Service, New Brunswick: Department of Justice

OECD (2005) Society at a Glance: OECD social indicators 2005, Paris: OECD

\section{- (2007) Society at a Glance: OECD social indicators} 2006, Paris: OECD

Pryor, J. \& B. Rodgers (2001) Children in Changing Families: life after parental separation, Oxford: Blackwell

Roy, F. (2006) 'From she to she: changing patterns of women in the Canadian labour force', Canadian Economic Observer, 19 (6), June (Statistics Canada)

Shirley, I., P. Koopman-Boyden, I. Pool \& S. St. John (1997) 'Family change and family policy in New Zealand', in S. Kamerman \& A. Kahn (eds), Family Change and Family Policies in Great Britain, Canada, New Zealand and the US, Oxford: Clarendon Press

Smyth, B. (ed.) (2004) Parent-Child Contact and PostSeparation Parenting Arrangements, research report 9, Melbourne: Australian Institute of Family Studies

Smyth, B., G. Sheehan \& B. Fehlberg (2001) 'Patterns of parenting after divorce: a benchmark study', Australian Journal of Family Law, 15 (2), pp.114-28

UK Child Support Agency (2003) www.csa.gov.uk

US Department of State, Office of Children's Issues (2003) 'Child Support Enforcement Abroad', www.acf. hhs.gov/programs/cse/extinf.html
Wu, Z. \& C. Schimmele (200) 'Divorce and repartnering', in M. Baker (ed.), Families: changing trends in Canada, 5th edition, Toronto: McGraw-Hill Ryerson, pp.202-8

Maureen Baker has been Professor of Sociology at the University of Auckland for the past $\mathbf{1 0}$ years, after lecturing and working as a researcher in Canada and Australia for the previous 23 years. She has published widely on family trends and crossnational family policies. 